\title{
The Problems Related to the Stocktaking of Forces and Resources in Internal Emergency Plans
}

\author{
SZENDI Rebeka ${ }^{1}$
}

\begin{abstract}
The laws, related to disaster management order the operators of dangerous establishments to prepare an internal emergency plan as the part of their safety documents. In this plan they describe the measures and resources for the protection against a possible industrial accident. Although the internal emergency plans of dangerous establishments are prepared mostly by the rules in effect, experiences show that lesser or greater problems may occur by preparing internal emergency plans, the inventory of the forces and resources is often not adequately detailed. The aim of this article is to present the problems related to force and resources calculations, respectively to give recommendations on the making of these calculations in a form which is easier to judge by the authority.
\end{abstract}

Keywords: dangerous establishment, internal emergency plan, industrial accident, protection measures, averting industrial accidents

\section{Introduction}

In line with Government Decree 219/2011 (XI. 10.) on the protection against major accidents involving dangerous substances (hereinafter: Decree), the operator of the establishment dealing with dangerous substances has to draw up an Internal Emergency Plan for the purpose of preventing risks set out in the safety report and safety analysis (hereinafter: SR and SA). [1] This document regulates the prevention, recovery and mitigation of major accidents involving dangerous substances as well as the order and conditions of information, alert and preparation. In addition, it also contains - as a compulsory item - the inventory of forces and resources available, which are necessary for protection against disasters. [2]

The purpose of this article is to present the problems related to the inventory of forces and resources in the Internal Emergency Plans based on personal experiences gained in this field, professional consultations as well as studying the internal emergency plans of dangerous establishments. Moreover, to give recommendations on a more transparent inventory of forces and resources, thereby facilitating the work of the authorities - by reviewing the relevant regulations and literature.

\section{Describing Forces and Resources}

\section{General Requirements}

The content requirements of internal emergency plans are specified by Annex VIII of the Decree. It is a general requirement that the tasks of preventing and averting accidents described

1 National University of Public Service Doctoral School of Military Engineering; Hungary, Budapest; E-mail: rebeka.szendi@katved.gov.hu 
in the plan are proportionate to the vulnerability assessed in the SR and the SA - as the Internal Emergency Plan is based on the SR and the SA. Furthermore, the organisations, forces and resources specified in the plan must be able to prevent major accidents and mitigate their consequences. [1]

The internal emergency plan has to address the situations following major accidents involving dangerous substances; tasks of controlling their effects; organisations, forces and equipment involved in the control; the infrastructure that can be involved in the control; facilities and materials that can be used and the measures and rules of conduct intended to protect the employees - within the framework of the tasks intended to prevent major accidents involving dangerous substances and to mitigate their effects. [1] Only those forces and equipment can be taken into account in the enumeration which are available. We cannot rely on tools which are not in use, the circumstances are not proper for their use (e.g. the lack of adequate power source), their technical compliance cannot be guaranteed or the employees are not prepared to use them. [3] It is important that the forces and equipment ensured by other regulations capable to execute the tasks defined in the plan are applicable to executing these tasks provided their duties are not affected and they meet the general requirements in the internal emergency plan (e.g. industrial fire brigades, chemical assessment teams). [4] In addition, the plan also has to include the forces and resources available under cooperation or mutual assistance. [5]

\section{Problems Related to the Description of Forces and Resources (Based on the Review of Internal Emergency Plans of Dangerous Establishments)}

When writing this article, internal emergency plans of several dangerous establishments have been reviewed which I became acquainted with during my work. Furthermore, the experiences used have been gathered during internal emergency plan exercises.

The internal emergency plans of dangerous establishments reveal that the establishments possess the protective equipment and gears in accordance with the (workplace safety, fire safety, environmental, etc.) legislation, such as personal protective equipment, fire extinguishers, fire hydrants, safety showers, eye washes, etc. It is a standard practice of the operators that the internal emergency plans simply list the forces and resources which are to be used in response and decontamination without a specific stocktaking of forces and resources mentioned above. It is very difficult for the authorities to judge whether the listed forces and resources are sufficient for the response. Furthermore, in certain cases the internal emergency drills point out that further resources are needed to carry out the operations properly and efficiently.

\section{Recommendations on the Stocktaking of Forces and Resources}

The wide variety of materials stored, produced or used in dangerous establishments and the applied technologies does not allow a general formula - applicable to all plants - to define the necessary forces and resources to be used in the response to various potential accidents.

There used to be guidelines based on the standards in certain regulations of the National Directorate General for Disaster Management (NDGDM) to calculate the forces and resources needed in firefighting, technical rescue as well as in chemical reconnaissance and decon- 
tamination. In the case of firefighting, the number of necessary and available extinguishers is specified based on the capacity of the extinguishers and the intended intensity:

$\Sigma \mathrm{N}_{\text {needed }}<\Sigma \mathrm{N}_{\text {available }}$

where $\Sigma \mathrm{N}$ : the number of fire extinguishers or equipment of a certain type;

and $\mathrm{N}=\mathrm{Q} / \mathrm{q}$

where Q: the needed intensity, q: the intensity of fire extinguishers or equipment of a certain type.

Through the determination of the capacity needs of technical rescue, the urgency of the operation is contrasted to the time (T) necessary to carry it out, which is the quotient of the volume of the rescue operation and the time available:

$\mathrm{T}_{\text {necessary }}>\mathrm{T}_{\text {possible }}$

where $T_{\text {necessary }}$ : the urgency of the operation; $T_{\text {possible }}=N / I$, where $N$ : the volume of the rescue operation (an item of the operation), I: the capacity of the staff unit (an item of the operation/h). To specify the forces and resources needed for chemical reconnaissance the following factors are essential: the number of released materials, their identification and the circumstances of the release. As regards chemical decontamination, the characteristics of released materials and the size of the damaged area are decisive factors. [6: 62-69] [7]

This article does not aim at covering the above mentioned standards in detail. The goal of the recommendations on the stocktaking of forces and resources is a uniform, properly-detailed stocktaking, thereby facilitating the work of the authorities. In this process, the relevant legislation and authoritative tasks of examining the documents are taken into account.

The following method is proposed for the operators to make calculations of forces and resources:

Analysing the main scenarios defined in the safety documents assess the minimum demand on sources and resources - if it is possible one by one ${ }^{2}-$ which are needed for the elimination of the situations described in the scenarios. Besides, we have to recon with the possibility of more events occurring simultaneously, resulting in increased needs. Next, the personnel and the technical infrastructure must be considered (event by event) which are available for the response or the mitigation of the consequences. When comparing the two, the number of resources available at least has to achieve - but, preferably outnumber - the necessary quantity. [8] Table 1 might provide help with stocktaking forces and resources.

The operator should also submit the event-specific inventory of forces and resources to the authorities as part of the review of internal emergency plans, so that the forces and resources that can be deployed in the response are more transparent for the authorities and they can set the minimum quantity.

The quantification of forces and resources necessary for various reconnaissance and response operations may pose difficulty due to the lack of specific legal requirements or guidelines. It would be reasonable to lay down the content requirements of the inventory of forces and resources.

2 When setting the requirements of forces and resources, the authority also has to examine the possibility or the necessity of treating each scenario separately (e.g. in establishments where dozens of scenarios are identified in the safety documents, it might be cumbersome). It might be more reasonable to compile a joint inventory for similar scenarios (e.g. release of dangerous chemicals, fire) or it may be enough to compile a general inventory for each scenario. 
SZENDI Rebeka: The Problems Related to the Stocktaking of Forces and Resources...

Table 1. Manual to prepare the inventory of forces and resources [Edited by the author]

\begin{tabular}{|c|c|c|c|}
\hline $\begin{array}{l}\text { Scenario } \\
\text { (based on SA/SR) }\end{array}$ & Operations to be carried out & $\begin{array}{l}\text { Detailed specification of the forces } \\
\text { - the necessary personnel (number } \\
\text { of persons) in each operation }\end{array}$ & $\begin{array}{l}\text { Detailed specification of the re- } \\
\text { sources needed in each operation }\end{array}$ \\
\hline \multirow[t]{11}{*}{ Scenario 1} & Reconnaissance & $\begin{array}{l}\text { - number of staff involved in the } \\
\text { operation } \\
\text { - their location } \\
\text { - alert protocol } \\
\text { - their qualification, preparation }\end{array}$ & $\begin{array}{l}\text { - personal protective equipment } \\
\text { (e.g. gas mask, oxygen tank, } \\
\text { protective clothing, etc.) } \\
\text { - the location of protective equip- } \\
\text { ment, access to them, distribution } \\
\text { - reconnaissance equipment (e.g. } \\
\text { detector tubes, detectors) }\end{array}$ \\
\hline & $\begin{array}{l}\text { Alarm } \\
\text { - executives } \\
\text { - staff } \\
\text { - disaster management } \\
\text { - authority }\end{array}$ & $\begin{array}{l}\text { - appointment of persons responsible } \\
\text { (who issues commands to whom?) }\end{array}$ & $\begin{array}{l}\text { - alarm devices (e.g. siren) } \\
\text { • communication devices }\end{array}$ \\
\hline & Command/Control & $\begin{array}{l}\text { - responsibilities, duties, } \\
\text { authority to issue instructions, } \\
\text { decision-making authority }\end{array}$ & $\begin{array}{l}\text { - command centre (location, facilities) } \\
\text { - computing devices } \\
\text { - communication devices } \\
\text { - etc. }\end{array}$ \\
\hline & $\begin{array}{l}\text { Fire fighting } \\
\text { (initial fire attack, localisation } \\
\text { before the arrival of professional } \\
\text { responders) }\end{array}$ & $\begin{array}{l}\text { - number of staff involved in the } \\
\text { operation } \\
\text { - their location } \\
\text { - alert protocol } \\
\text { - their qualification, preparation }\end{array}$ & $\begin{array}{l}\text { - necessary firefighting equipment } \\
\text { and facilities (quantity, capacity, } \\
\text { location) } \\
\text { - pumps e.g. at fire water storage } \\
\text { tanks (automatic, if not, who } \\
\text { starts it, where and how) }\end{array}$ \\
\hline & $\begin{array}{l}\text { Technical rescue } \\
\text { (operations that can be carried } \\
\text { out by the staff before the arrival } \\
\text { of professional responders) }\end{array}$ & $\begin{array}{l}\text { - number of staff involved in the } \\
\text { operation } \\
\text { - their location } \\
\text { - alert protocol } \\
\text { - their qualification, preparation }\end{array}$ & $\begin{array}{l}\text { - necessary technical devices } \\
\text { - their location }\end{array}$ \\
\hline & $\begin{array}{l}\text { Decontamination of the area } \\
\text { (operations that can be carried } \\
\text { out by the staff before the arrival } \\
\text { of professional responders) }\end{array}$ & $\begin{array}{l}\text { - number of staff involved in the } \\
\text { operation } \\
\text { - their location } \\
\text { - alert protocol } \\
\text { - their qualification, preparation }\end{array}$ & $\begin{array}{l}\text { - necessary devices and materials } \\
\text { for decontamination } \\
\text { - their location } \\
\text { - necessary protective equipment } \\
\text { - the location of equipment, access } \\
\text { to them, distribution }\end{array}$ \\
\hline & $\begin{array}{l}\text { Decontamination of the people } \\
\text { (operations that can be carried } \\
\text { out by the staff before the arrival } \\
\text { of professional responders) }\end{array}$ & $\begin{array}{l}\text { - number of (qualified) staff involved } \\
\text { in the operation (if available) } \\
\text { - their location } \\
\text { - alert protocol } \\
\text { - their qualification, preparation }\end{array}$ & $\begin{array}{l}\text { - necessary devices and materials } \\
\text { for personal decontamination } \\
\text { - their location }\end{array}$ \\
\hline & $\begin{array}{l}\text { Rescuing people } \\
\text { (operations that can be carried } \\
\text { out by the staff before the arrival } \\
\text { of professional responders) }\end{array}$ & $\begin{array}{l}\text { - number of (qualified) staff involved } \\
\text { in the operation (if available) } \\
\text { - their location } \\
\text { - alert protocol } \\
\text { - their qualification, preparation }\end{array}$ & $\begin{array}{l}\text { - rescue equipment (e.g. stretcher) } \\
\text { - their location }\end{array}$ \\
\hline & Medical care & $\begin{array}{l}\text { - number of (qualified) staff involved } \\
\text { in the operation (if available) e.g. } \\
\text { medical staff } \\
\text { - their location (the location of the } \\
\text { doctor's surgery, if available) }\end{array}$ & \\
\hline & $\begin{array}{l}\text { Communication } \\
\text { Alerting adjacent establishments }\end{array}$ & $\begin{array}{l}\text { - appointment of persons respon- } \\
\text { sible } \\
\text { (who issues commands to whom?) }\end{array}$ & $\begin{array}{l}\text { - alarm devices (e.g. siren) } \\
\text { • communication devices }\end{array}$ \\
\hline & $\begin{array}{l}\text { Evacuation of the area/ } \\
\text { Evacuation support } \\
\text { - administration }\end{array}$ & $\begin{array}{l}\text { - incident commander } \\
\text { - supervisors of the evacuation } \\
\text { - personnel responsible for the } \\
\text { administration of evacuation } \\
\text { assembly points }\end{array}$ & $\begin{array}{l}\text { - communication devices } \\
\text { - IT equipment needed for } \\
\text { administration }\end{array}$ \\
\hline
\end{tabular}

Note: The plan has to include the procedure of detecting the event as well as the procedure of the individual operations (e.g. alarming the intervention teams) outside working hours when no or just a limited number of employees are present 


\section{Summary}

According to the regulations, the operators of dangerous establishments have to draw up an internal emergency plan as part of their safety documentation. The law sets the requirements in the plan. It is a general expectation that the preventive and recovery tasks specified in the plan are proportionate to the threats listed in the SR and SA and that the bodies, forces and resources available are able to prevent major accidents and to mitigate their impact.

Experience shows that internal emergency plans of establishments generally comply with the regulations and contain the required items (tasks, forces, resources, description of the infrastructure, management, the identification of the individuals involved, etc.). However, these compulsory items are often just enumerated as a list and are not assigned to a certain event. The detailed, event-specific stocktaking of forces and resources is often absent, as the quantification of forces and resources necessary for various reconnaissance and response operations may pose difficulty without specific legal requirements or guidelines. Reasonably, the authority activities related to the examination, assessment and review of internal emergency plans (including the stocktaking of forces and resources) should extend to the specification of related requirements, guidelines and the possibility of introducing relevant legislation. The event-specific report on forces and resources and the description of the procedure would assist the authority with their activities of assessment, review and control.

\section{References}

[1] A veszélyes anyagokkal kapcsolatos súlyos balesetek elleni védekezésről szóló 219/2011. (X. 20.) Korm. rendelet. (Government Decree 219/2011 (XI. 10.) on the protection against major accidents involving dangerous substances.)

[2] 2011. évi CXXVIII. törvény a katasztrófavédelemről és a hozzá kapcsolódó egyes törvények módosításáról. (Law No. CXXVIII. of year 2011. on disaster management and the amendment of certain related laws.)

[3] SZAKÁL B., CIMER Zs., KÁTAI-URBÁN L., SÁROSI Gy., VASS Gy.: Iparbiztonság I. Veszélyes anyagok és súlyos baleseteik az iparban és a szállításban. Budapest: EX KOOP Bt. Nyomda, 2012. (Dangerous materials and their serious accidents in industry and transport, Technical book. In. Industrial safety I.)

[4] MÓGOR J.: Katasztrófavédelem. Budapest: Complex Kiadó Jogi és Üzleti Tartalomszolgáltató Kft., 2009. (Disaster management.)

[5] KOSSA Gy., KOZMA S., SZAKÁL B., VASS Gy.: Kézikönyv az iparbiztonsági üzemeltetői és hatósági feladatok ellátásához. In. BOGNÁR B., KÁTAI-URBÁN L. (Eds.), Iparbiztonságtan I. Budapest: NKE, 2013., 134-204. (Handbook for providing operational and magisterial tasks of industrial safety. In. Industrial safety I.).

[6] HOFFMANN I.: A védelmi tervezés és a kockázatcsökkentés jelentőségének kutatása a súlyos ipari balesetek elleni védekezésben. Budapest: ZMNE, 2007. PhD-értekezés-tervezet. (The research on the importance of defence planning and risk reduction by the protection against serious industrial accidents. Ph.D. dissertation draft.) 
SZENDI Rebeka: The Problems Related to the Stocktaking of Forces and Resources...

[7] SZAKÁL B., KÁTAI-URBÁN L., VASS Gy.: Veszélyes anyagok és ipari katasztrófák III. A veszélyes anyagokkal kapcsolatos súlyos balesetek életmentési-kárelhárítási feladatai. Budapest: SZIE-YMÉK, 2009. 76-80. Jegyzet (Dangerous materials and industrial disasters III., The life-saving - damage-averting tasks of serious accidents related to dangerous materials. Lecture notes.)

[8] DOBOR J., SZENDI R.: Vegyi felderítés és mentesítés a veszélyes üzemek belső védelmi terveiben - a belső védelmi tervekkel kapcsolatban felmerülő problémák. Hadtudományi Szemle, 71 (2014), 1-12. (Chemical reconnaissance and decontamination in the internal emergency plans of dangerous establishments - the problems emerging related to internal emergency plans.) 